\title{
A Comparative Study on Dimensions of Role Efficacy between Middle and Lower Management of Universities in Rajasthan
}

\author{
Chaudhary A. K.*, Jain N.**
}

\begin{abstract}
The performance of a person working in an organization depends on his own potential effectiveness, technical competence, managerial experience as well as the design of the role that he performs in the organization is called role efficacy. The purpose of the present research work is to compare role efficacy of middle and lower management employee's universities of Rajasthan. Respondents were directly contacted for filling up the standard questionnaire of Role Efficacy Scale, developed by Dr. Udai Pareek. The ten dimensions of role efficacy namely (Centrality, Self-role integration, Proactively, Creativity, Inter-role linkage, Helping relationship, Super ordination, Influence, Personal growth and Coordination) were analyzed through t-test. The results conclude that there is significant difference on dimensions inter role linkage, helping relationship and coordination of role efficacy of middle and lower management. The significance of the study is based on the challenges facing higher education and to improve their academic standard through role efficacy of middle and lower level management.
\end{abstract}

Keywords: Role efficacy, Middle management, Lower management

\section{INTRODUCTION}

The performance of a person working in an organization depends on his own potential effectiveness, technical competence, managerial experience as well as the design of the role that he performs in the organization is called role efficacy. The word "university" is derived from the Latin universities magistrorum ET scholarium, which roughly means "community of teachers and scholars." The university's employees played different roles in the university to execute various tasks. They have required proficiency to execute various tasks so we have to needed study of role efficacy of employees of universities. Role efficacy mean's a person's capacity for producing a desired result or effect; effectiveness. In other words it means potential effectiveness of an individual occupying a particular role in university.

*Senior Lecturer, Department of Psychology, Government Meera Girls College, Udaipur (Raj.)

**Research Scholar, Faculty of Management, Pacific University, Udaipur.

(C) 2014 Chaudhary A, Jain N; licensee IJIP. This is an Open Access Research distributed under the terms of the Creative Commons Attribution License (http://creativecommons.org/licenses/by/2.0), which permits unrestricted use, distribution, and reproduction in any Medium, provided the original work is properly cited. 


\section{A Comparative Study on Dimensions of Role Efficacy between Middle and Lower Management of Universities in Rajasthan}

\section{REVIEW OF LITERATURE}

Mahadevi. S. Waddar \& Vijaylaxmi A. Aminabhavi (2012) conducted research on topic "Role Based Performance and Role Efficacy of Aircraft Employees In Relation To Their Emotional Labour: A Study For Developing Employability Skill” Most discussion concerning today's work force eventually turn to employability skills. Finding workers who have employability or job readiness skills that help them fit into and remain in the work environment is a real problem. Employers need reliable, responsible skills and attitude to work together with other workers, especially in service interactions the management of service employee's emotion through emotional labour. The technique of correlation coefficient resulted in findings that all the two dependent variables namely role based performance and role efficacy are found to be significantly related with emotional labour. Finally, the interpreted results suggests the organizational development practitioner to plan and execute the intervention programs to enhance the emotional labour of the aircraft employees naturally without suppressing their emotions to make them to have better role based performance and role efficacy.

\section{OBJECTIVES OF THE STUDY:}

The objectives of the present research are as follows:

1. To study the role efficacy in the Middle and Lower Management employees of universities of Rajasthan.

2. To study the various dimensions of role efficacy namely Centrality, Self-role integration, Proactively, Creativity, Inter-role linkage, Helping relationship, Super ordination, Influence, Personal growth and Coordination of university employees.

3. To compare the various dimensions of role efficacy between Middle and Lower Management employees of universities.

\section{Methodology:}

First of all the head of the institutions were contacted and after taking permission for data collection, respondents were contacted at their comfort zone of time. Then the Role Efficacy Scale questionnaires were distributed and collected after 45 minutes. Thereafter scoring was done with the help of manual and interpretation was done. Thereafter t-test was applied for the comparison of middle and lower management university employees in the context of various dimensions of role efficacy.

\section{Tool:}

RES (Role Efficacy Scale) by Udai Pareek was used. The scale consists of 10 dimensions of role efficacy namely Centrality, Self-role integration, Proactively, Creativity, Inter-role linkage, Helping relationship, Superordination, Influence, Personal growth and Coordination. The test is reliable (reliable coefficient 0.68 ) and valid (validity coefficient 0.51 )

\section{Research Design}

Data were collected from 180 employees drawn from Public, Private and Deemed Universities. For testing the differences on present role efficacy between Middle and Lower Universities, the distribution of sample is as follows: Middle management $=90$ and Lower management $=90$. 


\section{Sample:}

The sample consisted of a total number of 90 employee's middle management and 90 employees lower management from six universities of Rajasthan.

\section{ANALYSIS AND DATA INTERPRETATION}

There will be no significant difference among Middle and Lower Management regarding dimensions of role efficacy namely Centrality, Self-role integration, Proactivity, Creativity, Inter-role linkage, Helping relationship, Super ordination, Influence, Personal growth and Coordination of University's employee.

Comparison of Middle and Lower Management on dimensions of Role efficacy

\begin{tabular}{|c|c|c|c|c|c|c|c|}
\hline Dimensions & $\begin{array}{c}\text { Type of } \\
\text { Management }\end{array}$ & $\mathbf{N}$ & Mean & S.D. & $\begin{array}{c}\text { Mean } \\
\text { Diff }\end{array}$ & $\mathbf{T}$ & $p$ value \\
\hline \multirow[t]{2}{*}{ Centrality } & Middle & 90 & 1.99 & .954 & \multirow[t]{2}{*}{.011} & \multirow[t]{2}{*}{.072} & \multirow[t]{2}{*}{.943} \\
\hline & Lower & 90 & 1.98 & 1.122 & & & \\
\hline \multirow{2}{*}{$\begin{array}{l}\text { Self-role } \\
\text { integration }\end{array}$} & Middle & 90 & 2.58 & 1.263 & \multirow[t]{2}{*}{.411} & \multirow[t]{2}{*}{1.604} & \multirow[t]{2}{*}{.111} \\
\hline & Lower & 90 & 2.17 & 2.079 & & & \\
\hline \multirow[t]{2}{*}{ Proactivity } & Middle & 90 & 1.86 & 1.303 & \multirow[t]{2}{*}{.333} & \multirow[t]{2}{*}{1.535} & \multirow[t]{2}{*}{.126} \\
\hline & Lower & 90 & 1.52 & 1.595 & & & \\
\hline \multirow[t]{2}{*}{ Creativity } & Middle & 90 & 2.59 & 1.101 & \multirow[t]{2}{*}{.333} & \multirow[t]{2}{*}{1.517} & \multirow[t]{2}{*}{.13} \\
\hline & Lower & 90 & 2.26 & 1.771 & & & \\
\hline \multirow[t]{2}{*}{ Inter-role linkage } & Middle & 90 & 2.42 & 1.236 & \multirow[t]{2}{*}{.544} & \multirow[t]{2}{*}{2.063} & \multirow[t]{2}{*}{.041} \\
\hline & Lower & 90 & 1.88 & 2.177 & & & \\
\hline \multirow{2}{*}{$\begin{array}{l}\text { Helping } \\
\text { relationship }\end{array}$} & Middle & 90 & 2.30 & 1.659 & \multirow[t]{2}{*}{.667} & \multirow[t]{2}{*}{2.102} & \multirow[t]{2}{*}{.037} \\
\hline & Lower & 90 & 1.63 & 2.510 & & & \\
\hline \multirow[t]{2}{*}{ Superordination } & Middle & 90 & 1.41 & 1.405 & \multirow[t]{2}{*}{.244} & \multirow[t]{2}{*}{1.013} & \multirow[t]{2}{*}{.312} \\
\hline & Lower & 90 & 1.17 & 1.807 & & & \\
\hline \multirow[t]{2}{*}{ Influence } & Middle & 90 & 1.93 & 1.339 & \multirow[t]{2}{*}{.189} & \multirow[t]{2}{*}{.840} & \multirow[t]{2}{*}{.402} \\
\hline & Lower & 90 & 1.74 & 1.660 & & & \\
\hline \multirow[t]{2}{*}{ Personal Growth } & Middle & 90 & 2.13 & 1.144 & \multirow[t]{2}{*}{.211} & \multirow[t]{2}{*}{1.072} & .285 \\
\hline & Lower & 90 & 1.92 & 1.478 & & & \\
\hline Coordination & Middle & 90 & 3.18 & 1.232 & .011 & 2.312 & .022 \\
\hline & Lower & 90 & 2.62 & 1.917 & & & \\
\hline
\end{tabular}




\section{A Comparative Study on Dimensions of Role Efficacy between Middle and Lower Management of Universities in Rajasthan}

The above table shows that ' $\mathrm{t}$ ' score for centraility dimension of role efficacy is found to be 0.072 which is insignificant at 0.05 level it infers that there is no significant difference on centrality dimension of role efficacy between middle and lower management. The above table indicates that ' $t$ ' score for self-role integration dimension of role efficacy is found to be 1.604 which is insignificant at 0.05 level it infers that there is no significant difference on self-role integration dimension of role efficacy between middle and lower management. The above table reflects that ' $t$ ' score for proactivity dimension of role efficacy is found to be 1.535 which is insignificant at 0.05 level it infers that there is no significant difference on proactivity dimension of role efficacy between middle and lower management. The above table depicts that ' $t$ ' score for creativity dimension of role efficacy is found to be 1.517 which is insignificant at 0.05 level it infers that there is no significant difference on creativity dimension of role efficacy between middle and lower management. The above table reveals that ' $t$ ' score for inter-role linkage dimension of role efficacy is found to be 2.063 which is significant at 0.05 level it infers that there is significant differences on inter-role linkage dimension of role efficacy between middle and lower management. The above table observes that ' $t$ ' score for helping relationship dimension of role efficacy is found to be 2.102 which is significant at 0.05 level it infers that there is significant differences on helping relationship dimension of role efficacy between middle and lower management. The above table refers that ' $\mathrm{t}$ ' score for super ordination dimension of role efficacy is found to be 1.013 which is insignificant at 0.05 level it infers that there is no significant difference on super ordination dimension of role efficacy between middle and lower management. The above table exhibits that ' $t$ ' score for influence dimension of role efficacy is found to be 0.540 which is insignificant at 0.05 level it infers that there is no significant difference on influence dimension of role efficacy between middle and lower management. The above table refers that ' $t$ ' score for personal growth dimension of role efficacy is found to be 1.072 which is insignificant at 0.05 level it infers that there is no significant difference on personal growth dimension of role efficacy between middle and lower management. The above table exhibits that ' $t$ ' score for coordination dimension of role efficacy is found to be 2.312 which is significant at 0.05 level it infers that there is significant differences on coordination dimension of role efficacy between middle and lower management.

\section{INTERPRETATION}

- Centrality dimension of Role Efficacy Middle and Lower management do not differs significantly on Centrality dimension of organizational role efficacy. It may be due to both types of management have similar level of potential effectiveness.

- Self Role Integration dimension of Role Efficacy Middle and Lower management do not differs significantly on Self Role Integration dimension of organizational role efficacy. Middle and Lower management have similar level of Self Role Integration. It may be due to both types of management executes similar nature of work and role at university level.

- Proactivity dimension of Role Efficacy Middle and Lower management do not differs significantly on Proactivity dimension of organizational role efficacy. It may be due to both 


\section{A Comparative Study on Dimensions of Role Efficacy between Middle and Lower Management of Universities in Rajasthan}

type of management executes all work according to issued orders by top management at university levels.

- Creativity dimension of Role Efficacy Middle and Lower management do not differs significantly on Creativity dimension of organizational role efficacy. Middle and Lower management having similar level of opportunity to be creative it may be due to perform routine task as per orders of Top management at university level.

- Inter Role Linkage dimension of Role Efficacy Middle and Lower management differs significantly on Inter Role Linkage dimension of organizational role efficacy. Middle management having more Inter Role Linkage in comparison to Lower management it may be due to Middle management executes mediator work between Top management and Lower management.

- Helping Relationship dimension of Role Efficacy Middle and Lower management differs significantly on Helping Relationship dimension of organizational role efficacy. Middle management had significantly more Helping Relationship from Lower management it may be due to Middle management executes all work with help to each other then Lower management.

- Super ordination dimension of Role Efficacy Middle and Lower management do not differs significantly on Super ordination dimension of organizational role efficacy at university level. It may be due to they have serve at similar level of systems, groups and entities beyond the organization.

- Influence dimension of Role Efficacy Middle and Lower management do not differ significantly on Influence dimension of organizational role efficacy. It may be due to they have similar power to Influence larger section of society.

- Personal Growth dimension of Role Efficacy Middle and Lower management do not differs significantly on Personal Growth dimension of organizational role efficacy. It may be due to Middle and Lower management employees have similar opportunities for personal growth.

- Coordination dimension of Role Efficacy Middle and Lower management differ significantly on Coordination dimension of organizational role efficacy. Middle management had significantly more Coordination from Lower management employees it may be due to Middle management are super position holders to listen the employee's problem and solve them then lower management employees.

\section{FINDINGS}

The Middle management performs better on Inter-role linkage, helping relationship, Coordination in comparison of Lower management. It was found that there is significant difference in dimension of role efficacy between middle and lower management.

\section{CONCLUSIONS}

There is significant difference between Middle and Lower management on dimensions Inter-role linkage, Helping Relationship and Coordination. 


\section{RECOMMENDATIONS}

1. Lower management required all three subsystems such as inter-role linkage, helping relationship and coordination.

2. The Role Efficacy refresher program for middle level management should be organized, so that employee can perform better. A separate program for lower management is the dire need of the time.

3. Lower management required to improve Inter-role linkage, Helping Relationship and Coordination dimensions of role efficacy through orientation programs.

\section{LIMITATION OF THE STUDY:}

This research is limited to the middle and lower management of educational sector of Rajasthan. This study relied on self report and surveyed data.

\section{REFERENCE}

1. Waddar S. M. \& Aminabhavi V. A. (2012) conducted research on topic "Role Based Performance And Role Efficacy Of Aircraft Employees In Relation To Their Emotional Labour: A Study For Developing Employability Skill'IJ.E.M.S., VOL.3(1) 2012: 24-28 ISSN 2229-600X 24 